\title{
Improving Response Rates to EGFR-Targeted Therapies for Head and Neck Squamous Cell Carcinoma: Candidate Predictive Biomarkers and Combination Treatment with Src Inhibitors
}

\author{
Ann Marie Egloff ${ }^{1}$ and Jennifer Rubin Grandis ${ }^{1,2,3}$ \\ ${ }^{1}$ Department of Otolaryngology, University of Pittsburgh, Pittsburgh, PA 15213, USA \\ ${ }^{2}$ Department of Pharmacology, University of Pittsburgh, Pittsburgh, PA 15213, USA \\ ${ }^{3}$ Eye and Ear Institute, Suite 500200 Lothrop Street, Pittsburgh, PA 15213, USA \\ Correspondence should be addressed to Jennifer Rubin Grandis, jgrandis@pitt.edu \\ Received 14 April 2009; Accepted 17 May 2009 \\ Recommended by Paul Harari
}

The epidermal growth factor receptor- (EGFR-) directed antibody, cetuximab, was FDA-approved for the treatment of squamous cell carcinoma of the head and neck (SCCHN) in 2006. Additional EGFR-targeting agents in clinical development for SCCHN include other EGFR-directed antibodies, tyrosine kinase inhibitors and antisense DNA. Although the majority of SCCHN overexpress EGFR, SCCHN clinical responses to EGFR-targeting agents have been modest. Molecular predictors for SCCHN response to EGFR-targeted therapies have not been identified. However, molecular correlate studies in lung cancer and colon cancer, which have EGFR-targeted therapeutics FDA-approved for treatment, may provide insights. We describe candidate predictive markers for SCCHN response to EGFR-targeted therapies and their prevalence in SCCHN. Clinical response will likely be improved by targeted therapy combination treatments. Src family kinases mediate EGFR-dependent and -independent tumor progression pathways in many cancers including SCCHN. Several Src-targeting agents are in clinical development for solid malignancies. Molecular correlate studies for Src-targeting therapies are few and biomarkers correlated with patient response are limited. Identifying SCCHN patients who will respond to combined EGFR- and Src-targeting will require further characterization of molecular correlates. We discuss rationale for EGFR and Src co-targeting for SCCHN treatment and describe recent clinical trials implementing combined Src- and EGFR-targeted therapeutics.

Copyright (C) 2009 A. M. Egloff and J. R. Grandis. This is an open access article distributed under the Creative Commons Attribution License, which permits unrestricted use, distribution, and reproduction in any medium, provided the original work is properly cited.

\section{Introduction}

Ninety-percent of head and neck cancers are squamous cell carcinomas (SCCHN) involving the mucosal surfaces of the oral cavity, pharynx, and larynx. The overall relative 5-year survival rates for cancers of the oral cavity/pharynx and larynx are estimated to be $58.3 \%$ and $64.5 \%$, respectively [1]. Morbidities associated with SCCHN and its treatments are significant and include eating and swallowing difficulties. Targeted therapies for SCCHN are under active investigation with the goals of reducing SCCHN morbidity and mortality.

Targeted therapeutics were conceptualized as a means of exploiting specific molecular alterations associated with cancers in order to selectively kill transformed cells and spare normal, healthy tissues. Targeted therapies are anticipated to have fewer associated toxicities than standard chemother- apies, which rely predominately on increased rates of cell division to enhance killing of the tumor cells compared to healthy tissues. For tumors that are treated with radiation and/or surgery, targeted therapies delivered systemically also have the potential to eliminate micrometastases that might not be eliminated with radiation therapy (RT) and/or surgery. In addition to reduced toxicity and treatment of undetected disease, it is hypothesized that effective targeted therapy may interfere specifically with processes that the cancer is dependent upon and be more effective than conventional therapies.

The epidermal growth factor receptor (EGFR) was anticipated to be a good drug target for SCCHN treatment because the majority of SCCHN overexpress EGFR [2,3], and higher tumor levels of EGFR are associated with poorer clinical outcomes $[4,5]$. EGFR participates in SCCHN autocrine 
stimulation, and overexpression of EGFR and its primary ligand in humans, transforming growth factor alpha (TGF- $\alpha$ ), have been correlated with poor outcomes for patients receiving therapy [5]. Cetuximab (Erbitux; ImClone Systems), a chimeric monoclonal IgG1 antibody directed against EGFR, was FDA-approved for the treatment of SCCHN in combination with RT for locally or regionally advanced disease and as a monotherapy for recurrent or metastatic SCCHN patients who have failed prior platinum-based therapy [6]. In addition to antibodies directed against EGFR, small molecule tyrosine kinase inhibitors (TKI) of EGFR and EGFR antisense agents are currently under active clinical investigation for SCCHN treatment. EGFR-targeted therapeutics delivered as monotherapies for treatment of SCCHN have demonstrated fewer toxicities compared to combined modality treatment regimens but only marginal clinical response (4$10 \%)[7,8]$. In general responses to EGFR-targeted therapies in SCCHN clinical trials have been modest.

Improving clinical response rates will involve (1) identifying SCCHN patients who are likely to respond to EGFRtargeted therapies, (2) developing effective combinations of targeted therapies, and (3) correctly identifying patients who will respond to specific targeted agents applied alone or in combination. Our understanding of the factors contributing to targeted therapy response now extends beyond the molecular alterations of the tumor to include host genetic variation. In this review, we will summarize molecular data correlated with clinical response to EGFR-targeted therapies and discuss factors that may be considered for identifying responsive SCCHN patients. Preclinical evidence suggests that Src family kinase-targeted agents administered in combination with EGFR-targeted therapies may demonstrate improved clinical response over EGFR-targeted agents alone. Here we also provide rationale for combining EGFR- and Src-targeted therapeutics for treatment of SCCHN, discuss published EGFR- and Src-combination treatment preclinical data, and summarize completed and ongoing clinical trials in solid tumors evaluating Src-targeted therapies in combination with EGFR-targeted therapies.

\section{EGFR-Targeted Therapies for SCCHN}

There are several EGFR-targeted therapies in clinical development for SCCHN, and these agents are described in Table 1. These inhibitors fall into two primary categories: EGFR-directed antibodies and EGFR tyrosine kinase inhibitors. EGFR-directed antibodies include cetuximab, nimotuzumab (YM Biosciences), panitumumab (Amgen), and zalutumumab (GenMab). EGFR-targeted tyrosine kinase inhibitors include erlotinib (Genetech and OSI Pharmaceuticals) and gefitinib (AstraZeneca). In addition to EGFR-targeted kinase inhibitors, inhibitors with broader target specificities are also in Phase II or III development for SCCHN including lapatinib (GlaxoSmithKline), which is a dual EGFR/HER2 inhibitor, and zactima (AstraZeneca), which targets VEGFR2 and RET in addition to EGFR (Table 1). More recently antisense therapy targeting EGFR has been evaluated in a Phase I clinical trial by our group [9].
Results of clinical trials for EGFR-targeted therapies cetuximab, nimotuzumab, gefitinib, and erlotinib used alone or in combination with conventional treatments for SCCHN have been reviewed by us and others and will not be described in detail here [10-12]. A Phase I study of panitumumab in combination with chemoradiotherapy involving 19-treatment-naïve patients with stage III/IV head and neck cancer reported an $87 \%$ complete response rate among the 15 evaluable patients and no grade 3 or 4 chronic toxicities [13]. A Phase I study of lapatinib in combination with chemoradiation in 31 patients with locally advanced SCCHN reported an overall response rate of $81 \%$ with radiation-associated mucositis, dermatitis, lymphopenia, and neutropenia as the most common grade 3 or 4 adverse events [14]. Our Phase I study of intratumoral delivery of EGFR antisense DNA in 17 patients with advanced, refractory SCCHN was associated with no grade 3 or 4 or dose-limiting toxicities and a clinical response rate (complete response and partial response by modified RECIST criteria) of 29\% [9]. The current phase of clinical development for each of these agents is presented in Table 1 .

\section{Predictors of Response to EGFR-Targeted Therapies}

To date, no molecular marker has been identified to correlate with SCCHN response to EGFR-targeting in patients. SCCHN tumor expression of the truncated form of EGFR, EGFR variant III (vIII), which lacks the ligand binding domain, occurs in up to $40 \%$ of SCCHN tumors and confers resistance to EGFR-targeted monoclonal antibodies in SCCHN preclinical models [15]. However, EGFR vIII expression and resistance to EGFR-targeted therapies in SCCHN patients has not been described. Molecular correlates of clinical response/nonresponse to EGFR-targeted therapies have been identified for colon and lung cancers. For example, the treatment of lung cancer with the EGFR tyrosine kinase inhibitor gefitinib demonstrated effective responses in a subset of patients whose lung cancers were subsequently found to harbor EGFR kinase activating mutations [16, 17]. Importantly, EGFR activating mutations do not appear to be frequent in SCCHN $[18,19]$. Therefore, some of these molecular correlates, such as the EGFR tyrosine kinase activating mutations are not applicable to SCCHN because the frequency of these mutations is very low and will not be discussed further in this review. However, other molecular correlates of response to EGFR-targeting agents have been described for lung cancer and colorectal cancers including EGFR gene amplification, other somatic tumor mutations and patient genetic variations. These biomarkers have potential utility as predictive markers for SCCHN.

3.1. Tumor EGFR Gene Amplification. EGFR gene amplification occurs in SCCHN, and the rate of reported EGFR gene amplification in SCCHN varies substantially (Table 2). To date, there are no published reports evaluating EGFR gene amplification for association with SCCHN patient response to EGFR-targeted therapies. However, EGFR gene 
TABLE 1: EGFR-targeted therapies in clinical development for SCCHN.

\begin{tabular}{|c|c|c|c|c|c|}
\hline \multicolumn{2}{|c|}{ Agent } & Sponsor & Class & FDA-approval & $\begin{array}{l}\text { Clinical trial phase for } \\
\text { SCCHN }\end{array}$ \\
\hline \multicolumn{6}{|c|}{ Antibodies } \\
\hline Cetuximab & $\begin{array}{l}\text { C225, } \\
\text { Erbitux }\end{array}$ & ImClone Systems & Chimeric IgG1 & $\begin{array}{l}\text { SCCHN; colorectal } \\
\text { cancers }\end{array}$ & III \\
\hline Nimotuzumab & h-R3 & YM Biosciences & Humanized IgG1 & - & $\begin{array}{l}\text { IV Advanced disease; } \\
\text { II Locally advanced } \\
\text { disease }\end{array}$ \\
\hline Panitumumab & $\begin{array}{l}\text { ABX-EGF; } \\
\text { Vectibix }\end{array}$ & Amgen & Fully human IgG2 & Colorectal cancers & III \\
\hline Zalutumumab & $\begin{array}{l}\text { HuMax- } \\
\text { EGFR }\end{array}$ & GenMab & Fully human IgG1 & - & III \\
\hline \multicolumn{6}{|c|}{ Tyrosine kinase inhibitors } \\
\hline Erlotinib & $\begin{array}{l}\text { Tarceva; } \\
\text { OSI-774 }\end{array}$ & $\begin{array}{l}\text { Genetech and OSI } \\
\text { Pharmaceuticals }\end{array}$ & Reversible ATP competive & Lung cancer & III \\
\hline Gefitinib & $\begin{array}{l}\text { ZD-1839; } \\
\text { Iressa }\end{array}$ & AstraZeneca & Reversible ATP competive & $\begin{array}{l}\text { Lung cancer, } \\
\text { relabeling limits }\end{array}$ & III \\
\hline Lapatinib & Tykerb & GlaxoSmithKline & $\begin{array}{l}\text { Reversible ATP competitive } \\
\text { dual EGFR/Her2 }\end{array}$ & Breast cancer & III \\
\hline Zactima & ZD6474 & AstraZeneca & $\begin{array}{l}\text { Reversible ATP competitive } \\
\text { VEGFR-2, EGFR and RET }\end{array}$ & - & II \\
\hline
\end{tabular}

amplification has been reported to be positively associated with response to EGFR-directed antibody therapies in clinical trials for nonsmall lung cancers (NSCLC) and colorectal cancers. In a phase II study of 229 NSCLC patients with advanced-stage NSCLC treated with cetuximab plus chemotherapy, 76 patient tumors were evaluated for EGFR gene amplification by FISH and disease controls rate (complete response/partial response and stable disease) was found to be significantly higher in patients with FISH-positive tumors compared to FISH-negative tumors ( $81 \%$ versus $55 \%, P=.02)$. In this same study, median progressionfree survival was also significantly longer for patients with FISH-positive tumors compared to FISH-negative tumors (6 months versus 3 months, $P=.0008$ ) [20]. Several studies have reported positive associations between EGFR gene amplification and metastatic colorectal cancer response to EGFR-directed antibodies [21-23].

EGFR gene amplification in SCCHN has been reported range between $10-58 \%$ of SCCHN (Table 2) [24-32]. The range of reported prevalence of EGFR gene amplification may be due to differences in expression by tumor anatomical site. However, several methods were used to assess EGFR gene amplification, including fluorescence in situ hybridization (FISH) and quantitative real-time polymerasechain reaction- (Q-PCR-) based assays. In addition, different scoring methods were employed in the studies presented in Table 2, some of which included polysomy in the definition for EGFR amplification and others did not. These differences in methodologies likely contribute to the variation in reported rates of EGFR gene amplification in SCCHN. The presence of EGFR gene amplification in a substantial portion of SCCHN and the previously reported associations between EGFR gene amplification and response to EGFRtargeted therapies in other cancers suggest that EGFR gene amplification may be a predictive marker for response to EGFR-targeted therapies in SCCHN. When evaluating EGFR gene amplification for correlation with response to EGFRtargeted agents, it will be important to develop consensus definitions of EGFR gene amplification.

EGFR gene amplification has not consistently been reported to correlate with EGFR protein levels although a plausible mechanism for gene amplification without protein overexpression is lacking [25, 28-30] (Table 2). In NSCLC and colon cancers a positive association between EGFR gene amplification and protein expression has also not been consistently observed [44, 45]. Importantly, EGFR gene amplification status, but not EGFR tumor protein levels, is associated with response to EGFR-targeted therapies in NSCLC and colorectal cancers. These discrepancies likely reflect the semiquantiatitve and variable methods of assessing gene amplification and protein expression levels in various laboratories. The characterization of EGFR gene amplification in SCCHN patients treated with EGFRdirected antibodies and the testing of association with response to therapy will be of interest.

3.2. Tumor KRAS/HRAS Mutations. Ras proteins are small GTPases that regulate signal transduction pathways leading to cell growth, differentiation, and survival. Three RAS genes produce four Ras proteins, $\mathrm{KraS} 4 \mathrm{~A}, \mathrm{KraS} 4 \mathrm{~B}, \mathrm{H}-\mathrm{Ras}$, and NRas, that are more than $90 \%$ homologous but demonstrate a high degree of tumor-type mutation specificity [46]. KRAS mutations have been reported by several independent groups to be negatively associated with response to EGFR tyrosine kinase inhibitors in lung cancer and EGFR-directed antibodies in colon cancer. A metaanalysis including 17 NSCLC EGFR tyrosine kinase inhibitor clinical studies with 1008 patient tumors and 8 metastatic colorectal cancer (mCRC) 
TABLE 2: Candidate predictive markers for SCCHN response to EGFR-targeted therapies.

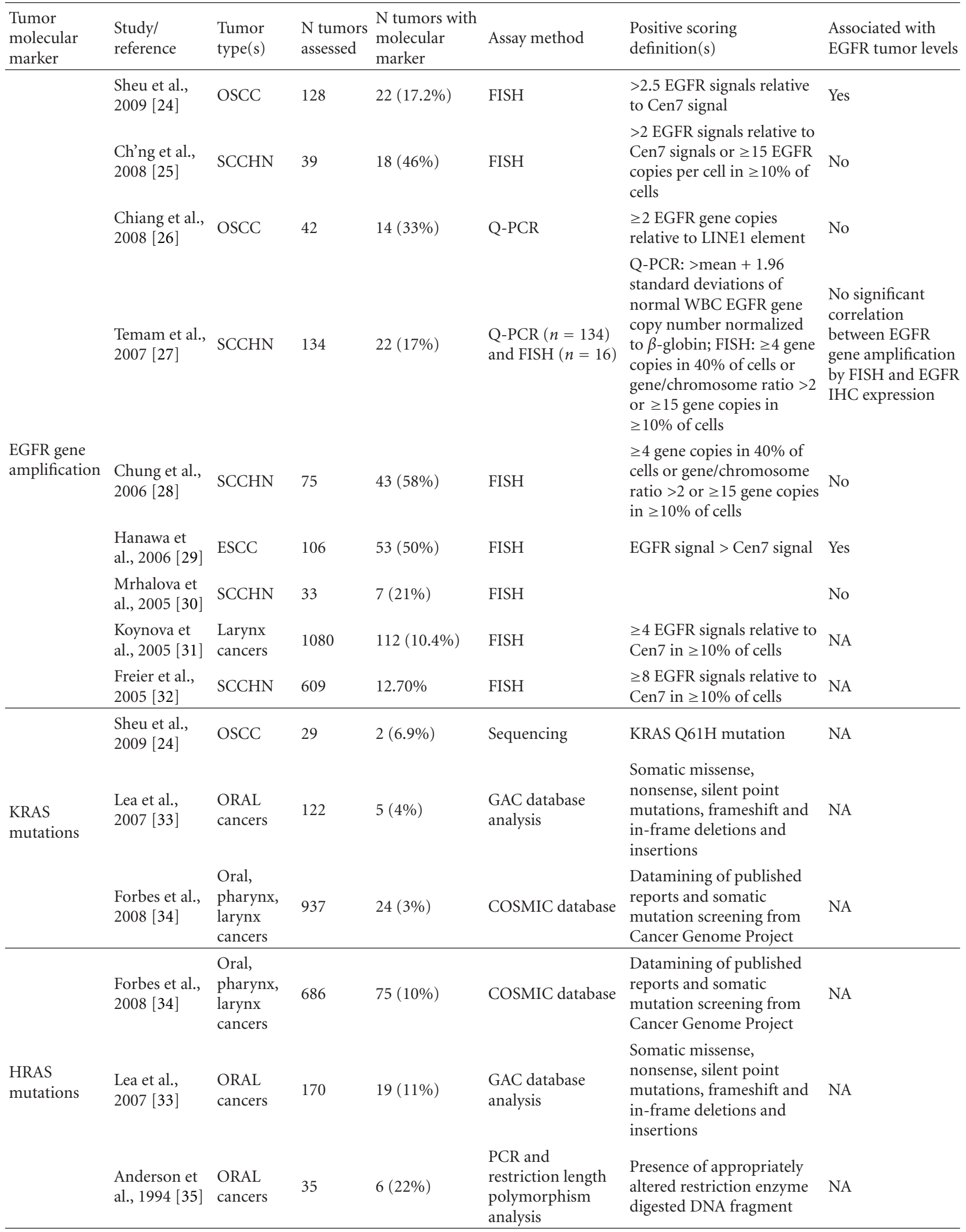


TABle 2: Continued.

\begin{tabular}{|c|c|c|c|c|c|c|c|}
\hline $\begin{array}{l}\text { Tumor } \\
\text { molecular } \\
\text { marker } \\
\end{array}$ & $\begin{array}{l}\text { Study/ } \\
\text { reference }\end{array}$ & $\begin{array}{l}\text { Tumor } \\
\text { type(s) }\end{array}$ & $\begin{array}{l}\mathrm{N} \text { tumors } \\
\text { assessed }\end{array}$ & $\begin{array}{l}\mathrm{N} \text { tumors with } \\
\text { molecular } \\
\text { marker }\end{array}$ & Assay method & $\begin{array}{l}\text { Positive scoring } \\
\text { definition(s) }\end{array}$ & $\begin{array}{l}\text { Associated with } \\
\text { EGFR tumor levels }\end{array}$ \\
\hline \multirow{4}{*}{$\begin{array}{l}\text { PI3KCA } \\
\text { mutations }\end{array}$} & $\begin{array}{l}\text { Murugan et } \\
\text { al., } 2008 \text { [36] }\end{array}$ & SCCHN & 37 & $2(5 \%)$ & $\begin{array}{l}\text { PCR and direct } \\
\text { sequencing exons } 9 \\
\text { and } 20\end{array}$ & $\begin{array}{l}\text { Somatic missense, } \\
\text { nonsense, frameshift, } \\
\text { in-frame deletions, and } \\
\text { insertions }\end{array}$ & NA \\
\hline & $\begin{array}{l}\text { Fenic et al., } \\
2007[37]\end{array}$ & SCCHN & 33 & $0(0 \%)$ & $\begin{array}{l}\text { PCR and direct } \\
\text { sequencing exons } 9 \\
\text { and } 20\end{array}$ & $\begin{array}{l}\text { Somatic missense } \\
\text { mutations }\end{array}$ & NA \\
\hline & $\begin{array}{l}\text { Qiu et al., } \\
2006[38]\end{array}$ & SCCHN & 38 & $4(11 \%)$ & $\begin{array}{l}\text { PCR and direct } \\
\text { sequencing exons } \\
1,4,5,6,7,9 \text {, and } \\
20\end{array}$ & $\begin{array}{l}\text { Somatic missense } \\
\text { mutations }\end{array}$ & NA \\
\hline & $\begin{array}{l}\text { Kozaki et al., } \\
2006[39]\end{array}$ & OSCC & 108 & $8(7 \%)$ & $\begin{array}{l}\text { PCR and direct } \\
\text { sequencing exons } 9 \\
\text { and } 20\end{array}$ & $\begin{array}{l}\text { Somatic missense } \\
\text { mutations }\end{array}$ & NA \\
\hline \multirow{4}{*}{$\begin{array}{l}\text { PTEN } \\
\text { mutations }\end{array}$} & $\begin{array}{l}\text { Shin et al., } \\
2002[40]\end{array}$ & OSCC & 86 & $4(5 \%)$ & $\begin{array}{l}\text { PCR and exon } \\
\text { direct sequencing }\end{array}$ & $\begin{array}{l}\text { Somatic missense, } \\
\text { nonsense, silent point } \\
\text { mutations, frameshift, } \\
\text { in-frame deletions, and } \\
\text { insertions }\end{array}$ & NA \\
\hline & $\begin{array}{l}\text { Poetsch et al., } \\
2002[41]\end{array}$ & SCCHN & 52 & $7(13 \%)$ & $\begin{array}{l}\text { PCR and exon } \\
\text { direct sequencing }\end{array}$ & $\begin{array}{l}\text { Somatic missense, } \\
\text { nonsense, frameshift, } \\
\text { in-frame deletions, and } \\
\text { insertions }\end{array}$ & NA \\
\hline & $\begin{array}{l}\text { Mavros et al., } \\
2002[42]\end{array}$ & OSCC & 50 & $0(0 \%)$ & $\begin{array}{l}\text { PCR and exon } \\
\text { direct sequencing }\end{array}$ & $\begin{array}{l}\text { Somatic missense, } \\
\text { nonsense, frameshift, } \\
\text { in-frame deletions, and } \\
\text { insertions }\end{array}$ & NA \\
\hline & $\begin{array}{l}\text { Shao et al., } \\
1998 \text { [43] }\end{array}$ & SCCHN & 19 & $3(16 \%)$ & $\begin{array}{l}\text { PCR and exon } \\
\text { direct sequencing }\end{array}$ & $\begin{array}{l}\text { Somatic missense, } \\
\text { nonsense, frameshift, } \\
\text { in-frame deletions, and } \\
\text { insertions }\end{array}$ & NA \\
\hline
\end{tabular}

Squamous cell carcinoma of the head and neck (SCCHN), oral squamous cell carcinoma (OSCC), esophageal squamous cell carcinoma (ESCC), fluorescence in situ hybridization (FISH), quantitative real-time polymerase chain reaction (PCR), centromere 7 (Cen7), Genetic Alterations in Cancer (GAC) database, and the Catalogue of Somatic Mutations in Cancer (COSMIC) database.

studies of anti-EGFR monoclonal antibody-based therapies in $817 \mathrm{mCRC}$ patients found that KRAS mutations were significantly associated with absence of response to EGFRtargeted therapies for these cancers [47]. KRAS mutations are especially important predictors of unresponsiveness to EGFR-directed antibodies in colorectal cancers with EGFR gene amplification [48]. Reported rates of KRAS mutations in NSCLC range between 8-20\% with higher rates reported for adenocarcinoma compared to squamous cell carcinoma histologies $[49,50]$. KRAS mutations occur in approximately $30 \%$ of colon cancers [51].

KRAS mutations are relatively rare in SCCHN. Only one published report has described KRAS mutations in SCCHN to date, and in this analysis of 29 oral squamous cell carcinoma tumors, $9(6.9 \%)$ were found to harbor KRAS mutations [24]. According to the Catalogue of Somatic Mutations in Cancer (COSMIC) database from the Sanger Institute, KRAS mutations occur in only approximately $3 \%$ of all cancers of the oral cavity, pharynx, or larynx while HRAS mutations occur in $10 \%$ of these cancers (Table 2)
[34]. These rates are similar to data from the Genetic Alterations in Cancer (GAC) database presented in Table 2 [33]. The recent finding that a mouse knock-in model expressing HRAS from the KRAS chromosomal context accumulated HRAS mutations and resulted in increased lung tumorigenicity suggests that tissue-specific expression of KRAS and HRAS likely contributes to tumor-type specificity of mutations in these two genes [52]. To date, only one published study of HRAS mutations SCCHN reported a 22\% rate of mutations in oral squamous cell carcinoma (Table 2) [35]. Mutations in HRAS are likely to be more common in SCCHN than KRAS mutations and may be important correlates for lack of response to EGFR-targeted therapies in SCCHN.

3.3. Tumor PI3K-AKT Pathway Mutations. Phosphatidylinositol 3-kinases (PI3Ks) are heterodimeric kinases composed of regulatory and catalytic subunits that are involved in the control of cell proliferation, survival, and motility. The PI3K catalytic subunit, P110alpha (PIK3CA) has been 
reported to be somatically mutated and activated in several cancers including SCCHN. Activation of PIK3CA leads to plasma membrane recruitment and activation of Akt and downstream survival mechanisms. PIK3CA mutations have been reported to be associated with resistance to EGFRtargeted monoclonal antibodies in patients with metastatic colorectal cancers (mCRC). In a study involving 110 patients with mCRC, PIK3CA mutations were found to be significantly associated with reduced objective response rates following treatment with cetuximab or panitumumab $(P=$ $.038)$ and shorter progression-free survival $(P=.035)$ [53]. PIK3CA mutations have been reported to occur in up to $8 \%$ of SCCHN as summarized in Table 2 [36-39].

PI3K signaling is inhibited by the activity of the phosphatidylinositol phosphatase, PTEN. PTEN acts as a tumor suppressor by negatively regulating the Akt signaling pathway. PTEN mutations occur in colorectal, lung, and head and neck cancers. Additionally, loss of PTEN expression occurs by mechanisms including promoter methylation and silencing or loss of heterozygosity. In SCCHN, PTEN mutations are not common (Table 2) [40-43], and loss of heterozygocity of PTEN has been reported to occur in approximately $12 \%$ of SCCHN [42]. Though the association with response to EGFR-targeted therapy in mCRC and loss of PTEN expression does not appear to be as strongly correlated as response and PIK3CA mutations [53], the consideration of both tumor PTEN expression status and PIK3CA mutation status may contribute to predicting response to EGFRtargeted therapies in SCCHN.

3.4. EGFR Polymorphisms. Several EGFR polymorphisms have been reported to be associated with differential response to EGFR-targeted therapies. In lung cancer, shorter EGFR intron $1 \mathrm{CA}$ repeat polymorphism has been reported to be associated with improved response to gefitinib in two independent studies $[54,55]$. In one study involving 70 patients with advanced NSCLC, patients with fewer than 17 CA repeats at either allele had significantly longer survival following treatment with gefitinib than patients having both alleles greater than $16 \mathrm{CA}$ repeats $(P=.039)$ [54]. Fewer EGFR intron 1 CA repeats were also significantly associated with mCRC patient response to cetuximab-based treatment in a study involving $110 \mathrm{mCRC}$ patients receiving combined cetuximab-irinotecan salvage therapy [56]. An independent study of 139 NSCLC patients with WHO performance status of 0 or 1 who received gefitinib reported that patients with the EGFR haplotype of $-216 \mathrm{G} /-191 \mathrm{C}$ had significantly worse survival with a hazard ratio of 1.85 (95\% CI: 1.09 to 3.12) after adjusting for performance status, previous platinum treatment, skin rash, and diarrhea [57]. The EGFR intron $1 \mathrm{CA}$ repeat polymorphism has been reported to affect EGFR basal transcription with higher transcription rates reported in individuals with fewer CA repeats $[58,59]$. Differential promoter activity has also been reported for the two most common EGFR haplotypes at the $-216 \mathrm{G}$ $>\mathrm{T}$ and $-191 \mathrm{C}>\mathrm{A}$ with the $-216 \mathrm{G} /-191 \mathrm{C}$ haplotype having lower promoter activity and mRNA expression [60, 61]. These studies, therefore, indicate that patient EGFR polymorphisms associated with higher EGFR expression are more likely to respond to EGFR-targeted therapies.

The presence of the EGFR K521R variant has also been found to be associated with significantly improved progression-free survival (PFS) and overall survival (OS) in 32 EGFR-positive mCRC patients treated with cetuximab in combination with irinotecan [62]. Patients with the K521R variant had significantly longer PFS than patients with wildtype EGFR, 5.7 months versus 3.2 months, respectively, $(P=$ .04 , log rank test) and OS, 20.1 months versus 13.8 months, respectively, $(P=.03)$ [62]. This EGFR variant, which resides in the extracellular domain of EGFR, has reduced ligand-binding, growth-stimulation, and kinase activity in vitro for the $521 \mathrm{~K}$ variant. These findings suggest that EGFR polymorphisms have the potential to be correlated with response to EGFR-targeted therapies in SCCHN.

3.5. FCyRIIa and FCyRIIIa Polymorphisms. Cetuximab, a chimeric monoclonal IgG1 anti-EGFR antibody (Table 1), may exert its antitumor effects via several mechanisms including antibody-dependent cell mediated cytotoxicity (ADCC). The fragment $\mathrm{c}(\mathrm{Fc})$ portion of IgG1 antibodies can be recognized by the $\mathrm{Fc}$ gamma receptors $(\mathrm{FC} \gamma \mathrm{R})$ on immune effector cells to induce ADCC. Polymorphisms in FC $\gamma$ RIIIa have been shown to be associated with differential response to cetuximab in $\mathrm{mCRC}$ patients in clinical studies and to SCCHN cell lines in vitro [63-65]. The FC $\gamma$ RIIIa polymorphism-V158F variant $158 \mathrm{~V}$ was found to have higher cetuximab-mediated ADCC in vitro $[64,65]$. The $158 \mathrm{~V}$ variant was also associated with longer PFS in a study involving $69 \mathrm{mCRC}$ patients treated with cetuximab plus irinotecan [63]. These findings indicate that FC $\gamma$ RIII variants may contribute to response to cetuximab in SCCHN patients.

The ability to correctly predict which patients will respond to which EGFR-targeted therapy will improve clinical response and reduce treatment-associated toxicities for these patients. However, the minority of SCCHN patients have responded to EGFR-targeted therapies in clinical trials, indicating that even if patients likely to respond to EGFRtargeted therapy were identified, they would represent a small portion of SCCHN patients. Even though the majority of SCCHN cancers overexpress EGFR, these tumors are not solely dependent upon EGFR activity. This is likely due to the presence of preexisting or treatment-induced compensatory signaling pathways. Because EGFR is activated in SCCHN and response to EGFR-targeted therapies has been demonstrated in clinical trials, it is reasonable to consider targeted therapies to be used in combination with EGFR-targeted therapeutics. Molecular signaling pathways in SCCHN that can be activated independently of EGFR include pathways initiated by G-protein-coupled receptors, integrins, and other receptor tyrosine kinases. Many of these pathways share Src family kinases (SFK) as downstream mediators of signaling. For these reasons, SFK have been identified as viable candidates for targeting in combination with EGFR. The combination of SFK- and EGFR-targeted agents for treatment of SCCHN is anticipated to have improved clinical efficacy compared to EGFR-targeting agents alone. 
TABLE 3: Src-targeting agents in clinical development.

\begin{tabular}{|c|c|c|c|c|c|c|c|c|c|}
\hline \multicolumn{2}{|c|}{ Agent } & \multirow{2}{*}{$\begin{array}{l}\text { Sponsor } \\
\text { Bristol-Myers } \\
\text { Squibb }\end{array}$} & \multirow{2}{*}{ 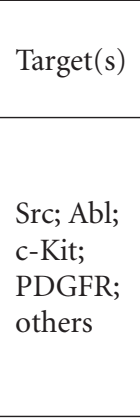 } & \multirow{2}{*}{$\begin{array}{l}\text { SFKs } \\
\text { targeted } \\
\text { (IC50) }\end{array}$} & \multirow{2}{*}{$\begin{array}{l}\text { Target site } \\
\text { ATP- } \\
\text { binding }\end{array}$} & \multirow{2}{*}{$\begin{array}{l}\text { Irreversible } \\
\\
\text { No }\end{array}$} & \multirow{2}{*}{$\begin{array}{l}\text { Solid cancers in } \\
\text { phase II or III } \\
\text { clinical study* } \\
\text { SCLC, NSCLC, } \\
\text { breast, } \\
\text { colorectal, head } \\
\text { and neck, liver, } \\
\text { melanoma, } \\
\text { ovarian, } \\
\text { pancreatic, } \\
\text { sarcoma }\end{array}$} & \multirow{2}{*}{$\begin{array}{l}\text { FDA approval } \\
\text { (Date) } \\
\\
\text { Chronic } \\
\text { myeloid } \\
\text { leukemia (June } \\
\text { 2006) }\end{array}$} & \multirow{2}{*}{$\begin{array}{l}\begin{array}{l}\text { SCCHN } \\
\text { clinical trial } \\
\text { phase }\end{array} \\
\text { II }\end{array}$} \\
\hline Dasatinib & $\begin{array}{l}\text { BMS- } \\
354825\end{array}$ & & & & & & & & \\
\hline AZD0530 & & AstraZeneca & Src; Abl & & $\begin{array}{l}\text { ATP- } \\
\text { binding }\end{array}$ & No & $\begin{array}{l}\text { SCLC, NSCLC, } \\
\text { breast, } \\
\text { colorectal, head } \\
\text { and neck, } \\
\text { melanoma, } \\
\text { osteosarcoma, } \\
\text { ovarian, } \\
\text { pancreatic, } \\
\text { prostate }\end{array}$ & - & II \\
\hline Bosutinib & SKI-606 & Wyeth & Src; Abl & & $\begin{array}{l}\text { ATP- } \\
\text { binding }\end{array}$ & No & Breast & - & - \\
\hline KX01 & $\begin{array}{l}\text { KX2- } \\
391 \\
\end{array}$ & Kinex & Src & & $\begin{array}{l}\text { Peptide- } \\
\text { binding }\end{array}$ & No & (phase I) & - & - \\
\hline XL999 & & Exelixis & $\begin{array}{l}\text { Src, } \\
\text { VEGFR, } \\
\text { PDGFR, } \\
\text { FGFR, } \\
\text { FLT-3, } \\
\text { others }\end{array}$ & & $\begin{array}{l}\text { ATP- } \\
\text { binding }\end{array}$ & No & $\begin{array}{l}\text { NSCLC, } \\
\text { colorectal, } \\
\text { kidney, ovarian }\end{array}$ & - & - \\
\hline
\end{tabular}

$*$ ClinicalTrials.gov solid tumors.

\section{Src Family Kinases in SCCHN}

Eight Src nonreceptor protein tyrosine kinase family members are expressed in humans: c-Src, Blk, Fgr, Fyn, Hck, Lck, Lyn, and c-Yes. c-Src, Fyn, Lyn, and c-Yes are broadly expressed, while Blk, Fgr, Hck, and Lck expression is primarily restricted to hematopoietic cells [66]. Src kinases have been implicated in normal cellular functions including cell adhesion, migration, angiogenesis, survival, proliferation, and differentiation $[67,68]$. When these processes are inappropriately regulated, they can contribute to tumorigenesis, tumor progression and metastases. In SCCHN models, Src kinases are activated in response to EGFR stimulation [69], associate with EGFR [69], and have reduced activity following EGFR inhibition in vitro [70]. Src kinases are also upstream activators of EGFR and other receptor tyrosine kinases (RTKs). Following G-protein-coupled receptor (GPCR) stimulation, Src kinases are activated, resulting in the release of RTK ligands [71, 72]. In addition to RTKs and GPCRs, Src kinases are also activated by integrins in SCCHN [73]. Src kinases, therefore, are involved in the autocrine/paracrine stimulation of SCCHN and mediate EGFR-dependent and EGFR-independent signaling events.

Of the Src family kinases (SFK), c-Src is the most studied and most often implicated in cancer. Elevated c-Src protein and/or kinase activity has been reported for cancers of the lung, colon, breast, ovary, and pancreas in addition to head and neck cancers $[68,74]$. c-Src is rarely mutated in cancer [74-76]. Therefore, increased activity of upstream signaling components and/or decreased activity of c-Src negative regulators are likely causes of c-Src activation observed in many epithelial cancers.

The expression and activation of specific SFK in SCCHN are less well understood. The SFK c-Src, Fyn, Lyn, and cYes are activated in SCCHN cell lines in vitro following stimulation with the EGFR ligand TGF- $\alpha$ [69], and these SFK likely play roles in SCCHN. At least one group has reported differential response of SFK to integrin $\beta_{6}$ signaling following simulation with fibronectin, the integrin $\beta_{6}$ ligand, in oral squamous cell carcinoma cell lines. Integrin $\beta_{6}$, which is neoexpressed in SCCHN, has been found to activate Fyn but not c-Src or c-Yes in SCCHN upon ligation with fibronectin, leading to Fyn-dependent activation of the RafERK/MAPK pathway [73]. The murine knock-out models of specific SFK provide insights into the different roles of the individual SFK. The functions of some of the SFKs are redundant, at least regarding mouse development, as evidenced by lack of phenotype for single knock-out models of c-yes, hck, c-fgr, and blk [66]. The single knock-out murine models of lyn and lck had immune impairments, fyn knock-out mice exhibited defective brain development and impaired memory and immune functions, and c-src 
null mice developed a bone remodeling disease with excess accumulation of bone [66]. Therefore, some functions are likely shared between the four SFKs with a subset of functions that may be unique to selective SFK.

\section{Src Family Kinases in SCCHN Invasion and Progression}

Mortality from SCCHN is usually associated with tumor invasion and locoregional metastases. The major site of SCCHN metastases is locoregional lymph nodes, and presence of neck lymph node metastases is universally accepted as the most important prognostic indicator for SCCHN. The development of metastases requires that cells move from the primary tumor and invade surrounding tissues. Invasion by tumor cells is preceded by the loss of cell adhesion and the gain of mesenchymal features in a process similar to events that occur in development termed epithelial-mesenchymal transition (EMT) [77]. EMT is accompanied by the loss of E-cadherin, which is a principal component of cell adhesion complexes, and the gain of mesenchymal characteristics including expression of vimentin [77].

The activation of Src kinases has been shown to be involved in EMT in cancer [78]. More recently, a study evaluating 50 primary SCCHN tumors for activated phospho-Src (P-Src), E-cadherin, and vimentin expression by immunohistochemical staining found increased P-Src, decreased Ecadherin, and presence of vimentin expression in SCCHN tumors to be significantly associated $(P<.05)$ with morphologies associated with aggressive cancers including penetrating invasive fronts, poor or sarcomatoid differentiation, and lymph node metastases [79]. It is important to note that the P-Src antibody used in this study recognizes several activated SFKs and is not specific for P-c-Src. In addition to studies in SCCHN tumors, preclinical studies indicate that SFKs are involved in SCCHN migration and invasion. Our group found that blockage using an Src-specific inhibitor A-419259 resulted in decreased invasion and growth of SCCHN cell lines in vitro following stimulation with a GPCR ligand, gastrin-releasing peptide [72]. An independent group reported that dasatinib (Sprycel, BMS-34825; Bristol-Meyers Squibb), a dual Src/Abl kinase inhibitor (Table 3), inhibited migration and invasion in vitro in all 8 SCCHN cell lines evaluated [80]. Together these studies implicate an important role or roles for SFK in tumor migration and invasion, which are associated with increased mortality in SCCHN. Which SFKs are activated in SCCHN migration and invasion is currently not known. Importantly, epithelial tumor cells including SCCHN that have undergone EMT and acquired mesenchymal characteristics are more resistant to EGFR-targeted therapies than tumor cells that have epithelial characteristics [81]. Combining Src-targeted agents with EGFR-targeted therapies may be more effective than EGFR-targeted therapies alone for the control of SCCHN locoregional metastases.

\section{Src-Targeting Agents in Clinical Development}

Several small molecule inhibitors of $\mathrm{c}$-Src and SFK are currently in clinical development for solid tumors including dasatinib (Sprycel, BMS), AZD0530 (AstraZeneca), bosutinib (SKI-606; Wyeth), XL999 (Exelixix), and KX01 (Kinex) (Table 3). All of these inhibitors are reversible inhibitors, and all except KX01 are ATP-competitive inhibitors (Table 3). These inhibitors differ primarily in their target specificities. Dasatinib and XL999 target several known kinases in addition to SFK (Table 3), while AZD0530 and bosutinib are dual SFK/Abl inhibitors. Dasatinib, which was FDAapproved for treatment of nonsolid tumors in June 2008, and AZD0530 are in Phase II clinical trials for SCCHN. Bosutinib and XL999 are in Phase II clinical trials for other cancers (Table 3). However, XL999, which inhibits VEGFR, PDGFR and FGFR in addition to Src kinases, was associated with serious cardiovascular toxicities in Phase I and II clinical trials [82-84]. Exelixis suspended new patient enrollment in the ongoing XL999 clinical trials in November 2006. A new addition to Src inhibitors in clinical development includes the c-Src substrate competitive inhibitor, KX01, which is currently being tested in phase I clinical trials. KX01 is exquisitely specific for $\mathrm{c}$-Src whereas other Src-targeting agents inhibit other SFK in addition to c-Src [85-87]. To date there are no reports of Src-targeted therapeutics in SCCHN clinical trials or molecular predictors of response to Srctargeted therapies in patients with solid malignancies.

\section{Cotargeting of EGFR and Src Family Kinases in Patients}

Combining EGFR- and Src-targeted therapies for SCCHN is supported by results from preclinical studies. Our group reported that combined AZD0530 and gefitinib treatment of SCCHN cell lines in vitro resulted in significantly reduced cell growth and invasion compared to single agent treatments [88]. De novo and acquired resistance to cetuximab are means by which SCCHN patients fail therapy.

SCCHN and NSCLC preclinical models selected for resistance to cetuximab in vitro have been reported to have high levels of activated SFK and to have decreased PI3K/Akt activity following dasatinib treatment [89]. Interestingly, these cetuximab resistant cells were found to be resensitized to cetuximab following treatment with dasatinib [89]. These data in addition to our current understanding that many EGFR-independent cell signaling pathways, including GPCR- and integrin-initiated pathways, are modulated at least in part by SFK provide the rationale for the combined targeting of EGFR and SFK for treatment of SCCHN.

To date, there are no published reports of combined EGFR- and Src-targeted therapies for treatment of patients with solid tumors. Three clinical trials combining EGFRand Src-targeted therapies for upper aerodigestive cancers are currently ongoing. A Phase I trial combining dasatinib with erlotinib in patients with recurrent NSCLC is ongoing at the H. Lee Moffitt Cancer Center and Research Institute (NCT00444015, ClincalTrials.gov). A Phase I/II study in NSCLC also combining dasatinib with erlotinib is ongoing at M.D. Anderson Cancer Center (NCT00826449, ClinicalTrials.gov). Our group will soon open a Phase 0 biomarker modulation study combining erlotinib with dasatinib for 
patients with SCCHN or NSCLC (NCT00779389, ClinicalTrials.gov). Results from these trials are not yet available. Our group recently completed a Phase I trial combining cetuximab with dasatinib for treatment of advanced solid malignancies (NCT00388427, ClinicalTrials.gov). Seventeen of 25 patients enrolled in our Phase I study were evaluable for response, and 9 had stable disease while head ache was a primary toxicity [90]. We have evaluated molecular correlates in these patients and found that P-SFK levels in peripheral blood mononuclear cells were transiently reduced following daily dasatinib dosing (unpublished data). In addition, we found that EGFR, TGF- $\alpha$, and amphiregulin plasma levels were altered following treatment (unpublished data). A Phase II study combining dasatinib and cetuximab for treating SCCHN patients is planned at the University of Pittsburgh Cancer Institute. Results from molecular correlate studies from this trial and others will be of great importance as the SCCHN medical and research communities work to identify predictive molecular markers of response to these therapies.

\section{Summary and Future Directions}

Despite the ubiquitous expression of EGFR in SCCHN, clinical responses to EGFR targeting agents, particularly, when administered as single agents, has been modest. Cetuximab was FDA-approved in 2006 for the treatment of newly diagnosed SCCHN in combination with radiation and recently extended to the recurrent/metastatic population in combination with chemoradiotherapy. However, in most of these trials, expression levels of EGFR in the tumor have not correlated with response to cetuximab and no single biomarker to date in baseline tissue has been proven to predict response to EGFR targeting agents. Comprehensive genomic and proteomic studies of baseline tissue are required in the context of clinical trials to begin to identify potential markers of clinical activity. Since EGFR signaling involves intracellular interactions with other oncogenic pathways in SCCHN preclinical models, it is plausible that cotargeting of EGFR in conjunction with blockade of these pathways may be beneficial. Src family kinases represent a potential pathway for targeting, especially given the FDA-approval of the Src kinase inhibitor dasatinib for hematopoietic malignancies. Studies are underway to test this hypothesis in SCCHN patients. Challenges include: (1) the difficulty of testing antiinvasive/antimetastatic agents in clinical trial settings, and (2) the possibility that RECIST criteria may not reflect decreased tumor proliferation, metabolism, or increased apoptosis as evidence by studies that have incorporated PET tracers. More relevant endpoints in EGFR-/Src-targeted trials than tumor shrinkage may include time to progression or overall survival. This may be especially relevant for locoregional recurrence/metastases in SCCHN [91].

\section{Acknowledgment}

The second author was supported by Grants no. P50 CA097190-06 and no. R01 CA77308.

\section{References}

[1] L. A. G. Ries, D. Melbert, M. Krapcho, et al., SEER Cancer Statistics Review, 2007.

[2] O. Dassonville, J. L. Formento, M. Francoual, et al., "Expression of epidermal growth factor receptor and survival in upper aerodigestive tract cancer," Journal of Clinical Oncology, vol. 11, no. 10, pp. 1873-1878, 1993.

[3] J. R. Grandis, M. F. Melhem, E. L. Barnes, and D. J. Tweardy, "Quantitative immunohistochemical analysis of transforming growth factor- $\alpha$ and epidermal growth factor receptor in patients with squamous cell carcinoma of the head and neck," Cancer, vol. 78, no. 6, pp. 1284-1292, 1996.

[4] K. K. Ang, N. H. Andratschke, and L. Milas, "Epidermal growth factor receptor and response of head-and-neck carcinoma to therapy," International Journal of Radiation Oncology Biology Physics, vol. 58, no. 3, pp. 959-965, 2004.

[5] J. R. Grandis, M. F. Melhem, W. E. Gooding, et al., "Levels of TGF- $\alpha$ and EGFR protein in head and neck squamous cell carcinoma and patient survival," Journal of the National Cancer Institute, vol. 90, no. 11, pp. 824-832, 1998.

[6] FDA approval for cetuximab, 2006.

[7] D. Soulieres, N. N. Senzer, E. E. Vokes, M. Hidalgo, S. S. Agarvala, and L. L. Siu, "Multicenter phase II study of erlotinib, an oral epidermal growth factor receptor tyrosine kinase inhibitor, in patients with recurrent or metastatic squamous cell cancer of the head and neck," Journal of Clinical Oncology, vol. 22, no. 1, pp. 77-85, 2004.

[8] E. E. W. Cohen, F. Rosen, W. M. Stadler, et al., "Phase II trial of ZD1839 in recurrent or metastatic squamous cell carcinoma of the head and neck," Journal of Clinical Oncology, vol. 21, no. 10, pp. 1980-1987, 2003.

[9] S. Y. Lai, P. Koppikar, S. M. Thomas, et al., "Intratumoral epidermal growth factor receptor antisense DNA therapy in head and neck cancer: first human application and potential antitumor mechanisms," Journal of Clinical Oncology, vol. 27, no. 8, pp. 1235-1242, 2009.

[10] P. M. Specenier and J. B. Vermorken, "Targeted therapies in head and neck cancer," Targeted Oncology, vol. 2, no. 2, pp. 73-88, 2007.

[11] A. M. Egloff and J. Grandis, "Epidermal growth factor receptor-targeted molecular therapeutics for head and neck squamous cell carcinoma," Expert Opinion on Therapeutic Targets, vol. 10, no. 5, pp. 639-647, 2006.

[12] E. E. W. Cohen, "Role of epidermal growth factor receptor pathway-targeted therapy in patients with recurrent and/or metastatic squamous cell carcinoma of the head and neck," Journal of Clinical Oncology, vol. 24, no. 17, pp. 2659-2665, 2006.

[13] L. J. Wirth, M. R. Posner, R. B. Tishler, et al., "Phase I study of pantitumumab + chemoradiotherapy (CRT) for head and neck cancer (HNC)," Journal of Clinical Oncology, vol. 26, p. 6007, 2008.

[14] K. J. Harrington, I. A. El-Hariry, C. S. Holford, et al., "Phase I study of lapatinib in combination with chemoradiation in patients with locally advanced squamous cell carcinoma of the head and neck," Journal of Clinical Oncology, vol. 27, no. 7, pp. 1100-1107, 2009.

[15] J. C. Sok, F. M. Coppelli, S. M. Thomas, et al., "Mutant epidermal growth factor receptor (EGFRvIII) contributes to head and neck cancer growth and resistance to EGFR targeting," Clinical Cancer Research, vol. 12, no. 17, pp. 50645073, 2006. 
[16] J. G. Paez, P. A. Jänne, J. C. Lee, et al., "EGFR mutations in lung, cancer: correlation with clinical response to gefitinib therapy," Science, vol. 304, no. 5676, pp. 1497-1500, 2004.

[17] T. J. Lynch, D. W. Bell, R. Sordella, et al., "Activating mutations in the epidermal growth factor receptor underlying responsiveness of non-small-cell lung cancer to gefitinib," New England Journal of Medicine, vol. 350, no. 21, pp. 2129-2139, 2004.

[18] J. Loeffler-Ragg, M. Witsch-Baumgartner, A. Tzankov, et al., "Low incidence of mutations in EGFR kinase domain in Caucasian patients with head and neck squamous cell carcinoma," European Journal of Cancer, vol. 42, no. 1, pp. 109-111, 2006.

[19] Y. Lemos-González, M. Páez de la Cadena, F. J. RodríguezBerrocal, A. M. Rodríguez-Piñeiro, E. Pallas, and D. Valverde, "Absence of activating mutations in the EGFR kinase domain in Spanish head and neck cancer patients," Tumor Biology, vol. 28, no. 5, pp. 273-279, 2007.

[20] F. R. Hirsch, R. S. Herbst, C. Olsen, et al., "Increased EGFR gene copy number detected by fluorescent in situ hybridization predicts outcome in non-small-cell lung cancer patients treated with cetuximab and chemotherapy," Journal of Clinical Oncology, vol. 26, no. 20, pp. 3351-3357, 2008.

[21] M. Moroni, S. Veronese, S. Benvenuti, et al., "Gene copy number for epidermal growth factor receptor (EGFR) and clinical response to antiEGFR treatment in colorectal cancer: a cohort study," Lancet Oncology, vol. 6, no. 5, pp. 279-286, 2005.

[22] F. Cappuzzo, G. Finocchiaro, E. Rossi, et al., "EGFR FISH assay predicts for response to cetuximab in chemotherapy refractory colorectal cancer patients," Annals of Oncology, vol. 19, no. 4, pp. 717-723, 2008.

[23] A. Sartore-Bianchi, M. Moroni, S. Veronese, et al., "Epidermal growth factor receptor gene copy number and clinical outcome of metastatic colorectal cancer treated with panitumumab," Journal of Clinical Oncology, vol. 25, no. 22, pp. 3238-3245, 2007.

[24] J. J.-C. Sheu, C.-H. Hua, L. Wan, et al., "Functional genomic analysis identified epidermal growth factor receptor activation as the most common genetic event in oral squamous cell carcinoma," Cancer Research, vol. 69, no. 6, pp. 2568-2576, 2009.

[25] S. Ch'ng, I. Low, D. Ng, et al., "Epidermal growth factor receptor: a novel biomarker for aggressive head and neck cutaneous squamous cell carcinoma," Human Pathology, vol. 39, no. 3, pp. 344-349, 2008.

[26] W.-F. Chiang, S.-Y. Liu, C.-Y. Yen, et al., "Association of epidermal growth factor receptor (EGFR) gene copy number amplification with neck lymph node metastasis in arecaassociated oral carcinomas," Oral Oncology, vol. 44, no. 3, pp. 270-276, 2008.

[27] S. Temam, H. Kawaguchi, A. K. El-Naggar, et al., "Epidermal growth factor receptor copy number alterations correlate with poor clinical outcome in patients with head and neck squamous cancer," Journal of Clinical Oncology, vol. 25, no. 16, pp. 2164-2170, 2007.

[28] C. H. Chung, K. Ely, L. McGavran, et al., "Increased epidermal growth factor receptor gene copy number is associated with poor prognosis in head and neck squamous cell carcinomas," Journal of Clinical Oncology, vol. 24, no. 25, pp. 4170-4176, 2006.

[29] M. Hanawa, S. Suzuki, Y. Dobashi, et al., "EGFR protein overexpression and gene amplification in squamous cell carcinomas of the esophagus," International Journal of Cancer, vol. 118, no. 5, pp. 1173-1180, 2006.

[30] M. Mrhalova, J. Plzak, J. Betka, and R. Kodet, "Epidermal growth factor receptor-its expression and copy numbers of EGFR gene in patients with head and neck squamous cell carcinomas," Neoplasma, vol. 52, no. 4, pp. 338-343, 2005.

[31] D. K. Koynova, V. S. Tsenova, and D. I. Toncheva, "Tissue microarray analysis of C-MYC oncogene copy number changes in larynx carcinoma," ORL, vol. 67, no. 2, pp. 92-95, 2005.

[32] K. Freier, C. Flechtenmacher, A. Walch, et al., "Copy number gains on $22 \mathrm{q} 13$ in adenoid cystic carcinoma of the salivary gland revealed by comparative genomic hybridization and tissue microarray analysis," Cancer Genetics and Cytogenetics, vol. 159, no. 1, pp. 89-95, 2005.

[33] I. A. Lea, M. A. Jackson, X. Li, S. Bailey, S. D. Peddada, and J. K. Dunnick, "Genetic pathways and mutation profiles of human cancers: site- and exposure-specific patterns," Carcinogenesis, vol. 28, no. 9, pp. 1851-1858, 2007.

[34] S. A. Forbes, G. Bhamra, S. Bamford, et al., "The catalogue of somatic mutations in cancer (COSMIC)," in Current Protocols in Human Genetics, chapter 10, unit 10 11, 2008.

[35] J. A. Anderson, J. C. Irish, C. M. McLachlin, and B. Y. Ngan, "H-ras oncogene mutation and human papillomavirus infection in oral carcinomas," Archives of Otolaryngology: Head and Neck Surgery, vol. 120, no. 7, pp. 755-760, 1994.

[36] A. K. Murugan, N. T. Hong, Y. Fukui, A. K. Munirajan, and N. Tsuchida, "Oncogenic mutations of the PIK3CA gene in head and neck squamous cell carcinomas," International Journal of Oncology, vol. 32, no. 1, pp. 101-111, 2008.

[37] I. Fenic, K. Steger, C. Gruber, C. Arens, and J. Woenckhaus, "Analysis of PIK3CA and Akt/protein kinase B in head and neck squamous cell carcinoma.," Oncology Reports, vol. 18, no. 1, pp. 253-259, 2007.

[38] W. Qiu, F. Schönleben, X. Li, et al., "PIK3CA mutations in head and neck squamous cell carcinoma," Clinical Cancer Research, vol. 12, no. 5, pp. 1441-1446, 2006.

[39] K.-I. Kozaki, I. Imoto, A. Pimkhaokham, et al., "PIK3CA mutation is an oncogenic aberration at advanced stages of oral squamous cell carcinoma," Cancer Science, vol. 97, no. 12, pp. 1351-1358, 2006.

[40] K. H. Shin, J. M. Kim, K. S. Rho, K. H. Park, J. E. Oh, and B. M. Min, "Inactivation of the PTEN gene by mutation, exonic deletion, and loss of transcript in human oral squamous cell carcinomas," International Journal of Oncology, vol. 21, no. 5, pp. 997-1001, 2002.

[41] M. Poetsch, G. Lorenz, and B. Kleist, "Detection of new PTEN/MMAC1 mutations in head and neck squamous cell carcinomas with loss of chromosome 10," Cancer Genetics and Cytogenetics, vol. 132, no. 1, pp. 20-24, 2002.

[42] A. Mavros, M. Hahn, I. Wieland, et al., "Infrequent genetic alterations of the tumor suppressor gene PTEN/MMAC1 in squamous cell carcinoma of the oral cavity," Journal of Oral Pathology and Medicine, vol. 31, no. 5, pp. 270-276, 2002.

[43] X. Shao, R. Tandon, G. Samara, et al., "Mutational analysis of the PTEN gene in head and neck squamous cell carcinoma," International Journal of Cancer, vol. 77, no. 5, pp. 684-688, 1998.

[44] S. Dacic, M. Flanagan, K. Cieply, et al., "Significance of EGFR protein expression and gene amplification in non-small cell lung carcinoma," American Journal of Clinical Pathology, vol. 125, no. 6, pp. 860-865, 2006.

[45] A. Ooi, T. Takehana, X. Li, et al., "Protein overexpression and gene amplification of HER-2 and EGFR in colorectal 
cancers: an immunohistochemical and fluorescent in situ hybridization study," Modern Pathology, vol. 17, no. 8, pp. 895904, 2004.

[46] A. Berns, "Kras and Hras-what is the difference?" Nature Genetics, vol. 40, no. 10, pp. 1149-1150, 2008.

[47] H. Linardou, I. J. Dahabreh, D. Kanaloupiti, et al., "Assessment of somatic k-RAS mutations as a mechanism associated with resistance to EGFR-targeted agents: a systematic review and meta-analysis of studies in advanced non-small-cell lung cancer and metastatic colorectal cancer," The Lancet Oncology, vol. 9, no. 10, pp. 962-972, 2008.

[48] F. Cappuzzo, M. Varella-Garcia, G. Finocchiaro, et al., "Primary resistance to cetuximab therapy in EGFR FISH-positive colorectal cancer patients," British Journal of Cancer, vol. 99, no. 1, pp. 83-89, 2008.

[49] F. Le Calvez, A. Mukeria, J. D. Hunt, et al., “TP53 and KRAS mutation load and types in lung cancers in relation to tobacco smoke: distinct patterns in never, former, and current smokers," Cancer Research, vol. 65, no. 12, pp. 5076-5083, 2005.

[50] H. Shigematsu, L. Lin, T. Takahashi, et al., "Clinical and biological features associated with epidermal growth factor receptor gene mutations in lung cancers," Journal of the National Cancer Institute, vol. 97, no. 5, pp. 339-346, 2005.

[51] E. S. Schernhammer, E. Giovannuccci, C. S. Fuchs, and S. Ogino, "A prospective study of dietary folate and vitamin B and colon cancer according to microsatellite instability and KRAS mutational status," Cancer Epidemiology Biomarkers and Prevention, vol. 17, no. 10, pp. 2895-2898, 2008.

[52] M. D. To, C. E. Wong, A. N. Karnezis, R. Del Rosario, R. Di Lauro, and A. Balmain, "Kras regulatory elements and exon 4A determine mutation specificity in lung cancer," Nature Genetics, vol. 40, no. 10, pp. 1240-1244, 2008.

[53] A. Sartore-Bianchi, M. Martini, F. Molinari, et al., "PIK3CA mutations in colorectal cancer are associated with clinical resistance to EGFR-targeted monoclonal antibodies," Cancer Research, vol. 69, no. 5, pp. 1851-1857, 2009.

[54] Q. Nie, Z. Wang, G. Zhang, et al., "The epidermal growth factor receptor intron1 (CA) $\mathrm{n}$ microsatellite polymorphism is a potential predictor of treatment outcome in patients with advanced lung cancer treated with Gefitinib," European Journal of Pharmacology, vol. 570, no. 1-3, pp. 175-181, 2007.

[55] M. Tiseo, M. Capelletti, G. De Palma, et al., "Epidermal growth factor receptor intron-1 polymorphism predicts gefitinib outcome in advanced non-small cell lung cancer," Journal of Thoracic Oncology, vol. 3, no. 10, pp. 1104-1111, 2008.

[56] F. Graziano, A. Ruzzo, F. Loupakis, et al., "Pharmacogenetic profiling for cetuximab plus irinotecan therapy in patients with refractory advanced colorectal cancer," Journal of Clinical Oncology, vol. 26, no. 9, pp. 1427-1434, 2008.

[57] V. Gregorc, M. Hidalgo, A. Spreafico, et al., "Germline polymorphisms in EGFR and survival in patients with lung cancer receiving gefitinib," Clinical Pharmacology and Therapeutics, vol. 83, no. 3, pp. 477-484, 2008.

[58] F. Gebhardt, H. Bürger, and B. Brandt, "Modulation of EGFR gene transcription by a polymorphic repetitive sequence-a link between genetics and epigenetics," International Journal of Biological Markers, vol. 15, no. 1, pp. 105-110, 2000.

[59] M.-C. Etienne-Grimaldi, S. Pereira, N. Magné, et al., "Analysis of the dinucleotide repeat polymorphism in the epidermal growth factor receptor (EGFR) gene in head and neck cancer patients," Annals of Oncology, vol. 16, no. 6, pp. 934-941, 2005.

[60] W. Liu, F. Innocenti, M. H. Wu, et al., "A functional common polymorphism in a $\mathrm{Sp} 1$ recognition site of the epidermal growth factor receptor gene promoter," Cancer Research, vol. 65, no. 1, pp. 46-53, 2005.

[61] M. Nomura, H. Shigematsu, L. Li, et al., "Polymorphisms, mutations, and amplification of the EGFR gene in non-small cell lung cancers," PLoS Medicine, vol. 4, no. 4, article e125, 2007.

[62] A. Gonçalves, S. Esteyries, B. Taylor-Smedra, et al., "A polymorphism of EGFR extracellular domain is associated with progression free-survival in metastatic colorectal cancer patients receiving cetuximab-based treatment," BMC Cancer, vol. 8, article 169, 2008.

[63] F. Bibeau, E. Lopez-Crapez, F. Di Fiore, et al., "Impact of Fc $\gamma$ RIIa-Fc $\gamma$ RIIIa polymorphisms and KRAS mutations on the clinical outcome of patients with metastatic colorectal cancer treated with cetuximab plus irinotecan," Journal of Clinical Oncology, vol. 27, no. 7, pp. 1122-1129, 2009.

[64] A. López-Albaitero, S. C. Lee, S. Morgan, et al., "Role of polymorphic Fc gamma receptor IIIa and EGFR expression level in cetuximab mediated, NK cell dependent in vitro cytotoxicity of head and neck squamous cell carcinoma cells," Cancer Immunology, Immunotherapy. In press.

[65] R. J. Taylor, S.-L. Chan, A. Wood, et al., "Fc $\gamma$ RIIIa polymorphisms and cetuximab induced cytotoxicity in squamous cell carcinoma of the head and neck," Cancer Immunology, Immunotherapy, vol. 58, no. 7, pp. 997-1006, 2009.

[66] C. A. Lowell and P. Soriano, "Knockouts of Src-family kinases: stiff bones, wimpy T cells, and bad memories," Genes and Development, vol. 10, no. 15, pp. 1845-1857, 1996.

[67] S. M. Thomas and J. S. Brugge, "Cellular functions regulated by SRC family kinases," Annual Review of Cell and Developmental Biology, vol. 13, pp. 513-609, 1997.

[68] J. M. Summy and G. E. Gallick, "Src family kinases in tumor progression and metastasis," Cancer and Metastasis Reviews, vol. 22, no. 4, pp. 337-358, 2003.

[69] S. Xi, Q. Zhang, K. F. Dyer, et al., "Src kinases mediate STAT growth pathways in squamous cell carcinoma of the head and neck," Journal of Biological Chemistry, vol. 278, no. 34, pp. 31574-31583, 2003.

[70] Z. Yang, R. Bagheri-Yarmand, R.-A. Wang, et al., "The epidermal growth factor receptor tyrosine kinase inhibitor ZD1839 (Iressa) suppresses c-Src and Pak1 pathways and invasiveness of human cancer cells," Clinical Cancer Research, vol. 10, no. 2, pp. 658-667, 2004.

[71] Q. Zhang, S. M. Thomas, V. W. Y. Lui, et al., "Phosphorylation of TNF- $\alpha$ converting enzyme by gastrin-releasing peptide induces amphiregulin release and EGF receptor activation," Proceedings of the National Academy of Sciences of the United States of America, vol. 103, no. 18, pp. 6901-6906, 2006.

[72] Q. Zhang, S. M. Thomas, S. Xi, et al., "Src family kinases mediate epidermal growth factor receptor ligand cleavage, proliferation, and invasion of head and neck cancer cells," Cancer Research, vol. 64, no. 17, pp. 6166-6173, 2004.

[73] X. Li, Y. Yang, Y. Hu, et al., " $\alpha v \beta 6$-Fyn signaling promotes oral cancer progression," Journal of Biological Chemistry, vol. 278, no. 43, pp. 41646-41653, 2003.

[74] R. B. Irby and T. J. Yeatman, "Role of Src expression and activation in human cancer," Oncogene, vol. 19, no. 49, pp. 5636-5642, 2000.

[75] Y. Daigo, Y. Furukawa, T. Kawasoe, et al., "Absence of genetic alteration at codon 531 of the human c-src gene in 479 advanced colorectal cancers from Japanese and Caucasian patients," Cancer Research, vol. 59, no. 17, pp. 4222-4224, 1999. 
[76] M. Nilbert and E. Fernebro, "Lack of activating c-SRC mutations at codon 531 in rectal cancer," Cancer Genetics and Cytogenetics, vol. 121, no. 1, pp. 94-95, 2000.

[77] N. Gavert and A. Ben-Ze'ev, "Epithelial-mesenchymal transition and the invasive potential of tumors," Trends in Molecular Medicine, vol. 14, no. 5, pp. 199-209, 2008.

[78] P. Savagner, "Leaving the neighborhood: molecular mechanisms involved during epithelial-mesenchymal transition," BioEssays, vol. 23, no. 10, pp. 912-923, 2001.

[79] M. Mandal, J. N. Myers, S. M. Lippman, et al., "Epithelial to mesenchymal transition in head and neck squamous carcinoma: association of Src activation with E-cadherin down-regulation, vimentin expression, and aggressive tumor features," Cancer, vol. 112, no. 9, pp. 2088-2100, 2008.

[80] F. M. Johnson, B. Saigal, M. Talpaz, and N. J. Donato, "Dasatinib (BMS-354825) tyrosine kinase inhibitor suppresses invasion and induces cell cycle arrest and apoptosis of head and neck squamous cell carcinoma and non-small cell lung cancer cells," Clinical Cancer Research, vol. 11, no. 19, pp. 6924-6932, 2005.

[81] S. Barr, S. Thomson, E. Buck, et al., "Bypassing cellular EGF receptor dependence through epithelial-to- mesenchymal-like transitions," Clinical and Experimental Metastasis, vol. 25, no. 6, pp. 685-693, 2008.

[82] J. Cooper, M. M. Mita, J. Curtright, et al., "A phase I study examining weekly dosing and pharmacokinetics (PK) of a novel spectrum selective kinase inhibitor, XL999, in patients (pts) with advanced solid malignancies (ASM)," Journal of Clinical Oncology, vol. 24, no. 18, supplement, 2006, abstract no. 13024.

[83] L. Cripe, W. McGuire, M. Wertheim, et al., "Integrated report of the phase 2 experience with XL999 administered IV to patients (pts) with NSCLC, renal cell CA (RCC), metastatic colorectal CA (CRC), recurrent ovarian CA, accute myelogenous leaukemia (AML), and multiple myeloma (MM)," Journal of Clinical Oncology, vol. 25, no. 18, supplement, 2007, abstract no. 3591.

[84] R. J. March, B. Mirtsching, S. Modi, et al., "A phase II study of XL999 in patients (pts) with NSCLC," Journal of Clinical Oncology, vol. 25, no. 18, supplement, 2007, abstract no. 18112.

[85] D. Hangauer, I. Gelman, L. Dyster, et al., "Potent and selective in vitro and in vivo inhibition of tumor proliferation by KX01, a novel non-ATP competitive Src inhibitor," in Proceedings of the AACR Meeting, 2007, abstracts no. 3245.

[86] L. J. Lombardo, F. Y. Lee, P. Chen, et al., "Discovery of N-(2-chloro-6-methylphenyl)-2-(6-(4-(2-hydroxyethyl)piperazin-1-yl)-2-methylpyrimidin-4-ylamino)thiazole-5carboxamide (BMS-354825), a dual Src/Abl kinase inhibitor with potent antitumor activity in preclinical assays," Journal of Medicinal Chemistry, vol. 47, no. 27, pp. 6658-6661, 2004.

[87] L. F. Hennequin, J. Allen, J. Breed, et al., "N-(5-chloro-1,3benzodioxol-4-yl)-7-[2-(4-methylpiperazin-1-yl)ethoxy] -5(tetrahydro-2H-pyran-4-yloxy)quinazolin-4-amine, a novel, highly selective, orally available, dual-specific c-Src/Abl kinase inhibitor," Journal of Medicinal Chemistry, vol. 49, no. 22, pp. 6465-6488, 2006.

[88] P. Koppikar, S.-H. Choi, A. M. Egloff, et al., "Combined inhibition of c-Src and epidermal growth factor receptor abrogates growth and invasion of head and neck squamous cell carcinoma," Clinical Cancer Research, vol. 14, no. 13, pp. 4284-4291, 2008.

[89] D. L. Wheeler, M. Iida, T. J. Kruser, et al., "Epidermal growth factor receptor cooperates with Src family kinases in acquired resistance to cetuximab," Cancer Biology and Therapy, vol. 8, no. 8, pp. 696-703, 2009.

[90] T. M. Fieinstein, S. Agrawal, R. G. Stoller, et al., "Phase I and pharmacokinetic (PK) study of dasatinib (D) and cetuximab (C) in patients (pts) with advanced solid malignancies," in Proceedings of the ASCO, 2009.

[91] A. A. Adjei, M. Christian, and P. Ivy, "Novel designs and end points for phase II clinical trials," Clinical Cancer Research, vol. 15, no. 6, pp. 1866-1872, 2009. 


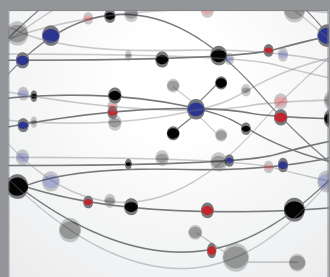

The Scientific World Journal
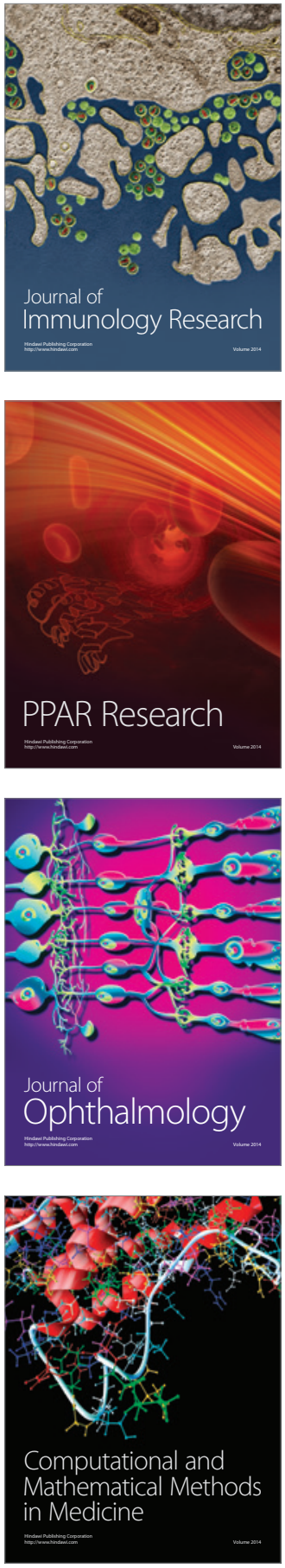

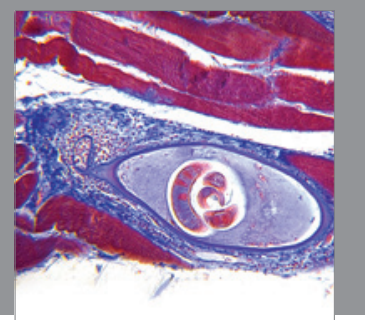

Gastroenterology

Research and Practice
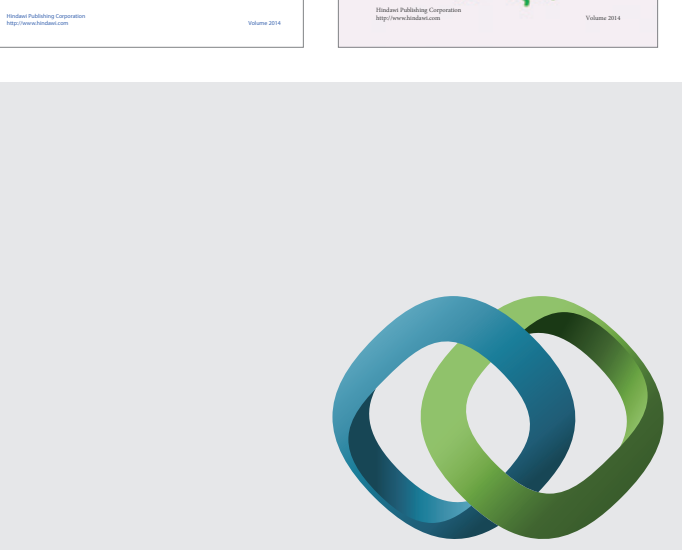

\section{Hindawi}

Submit your manuscripts at

http://www.hindawi.com
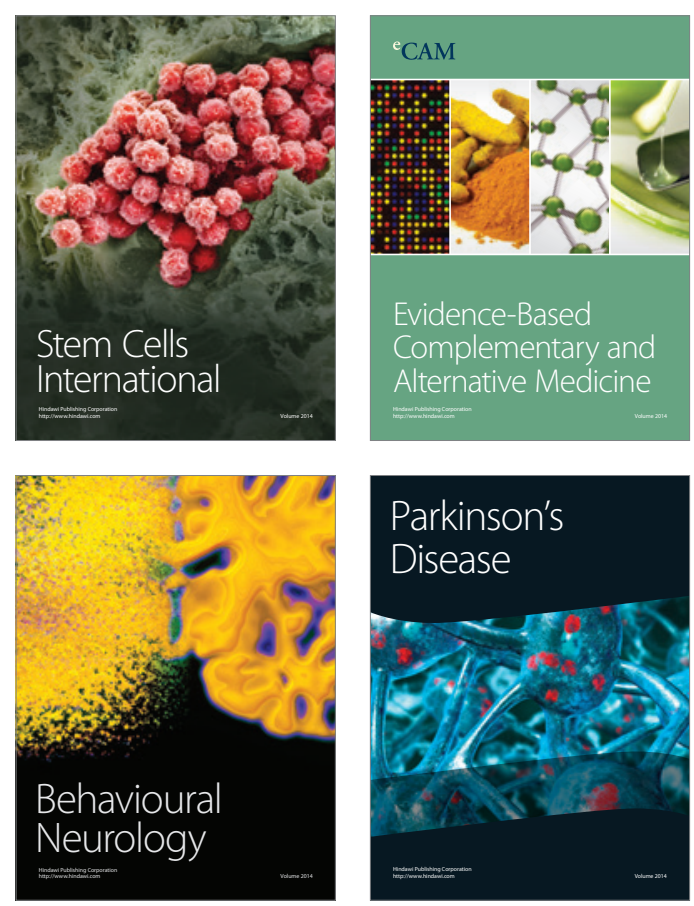

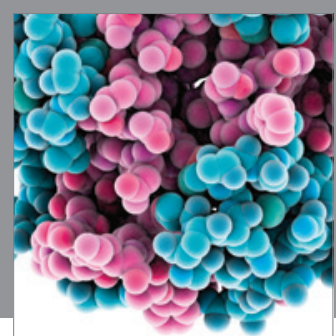

Journal of
Diabetes Research

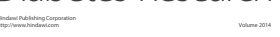

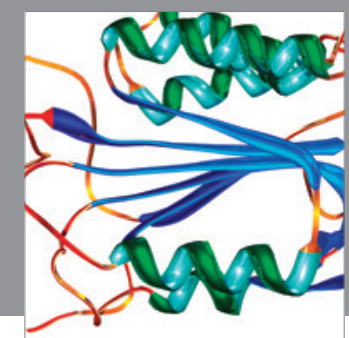

Disease Markers
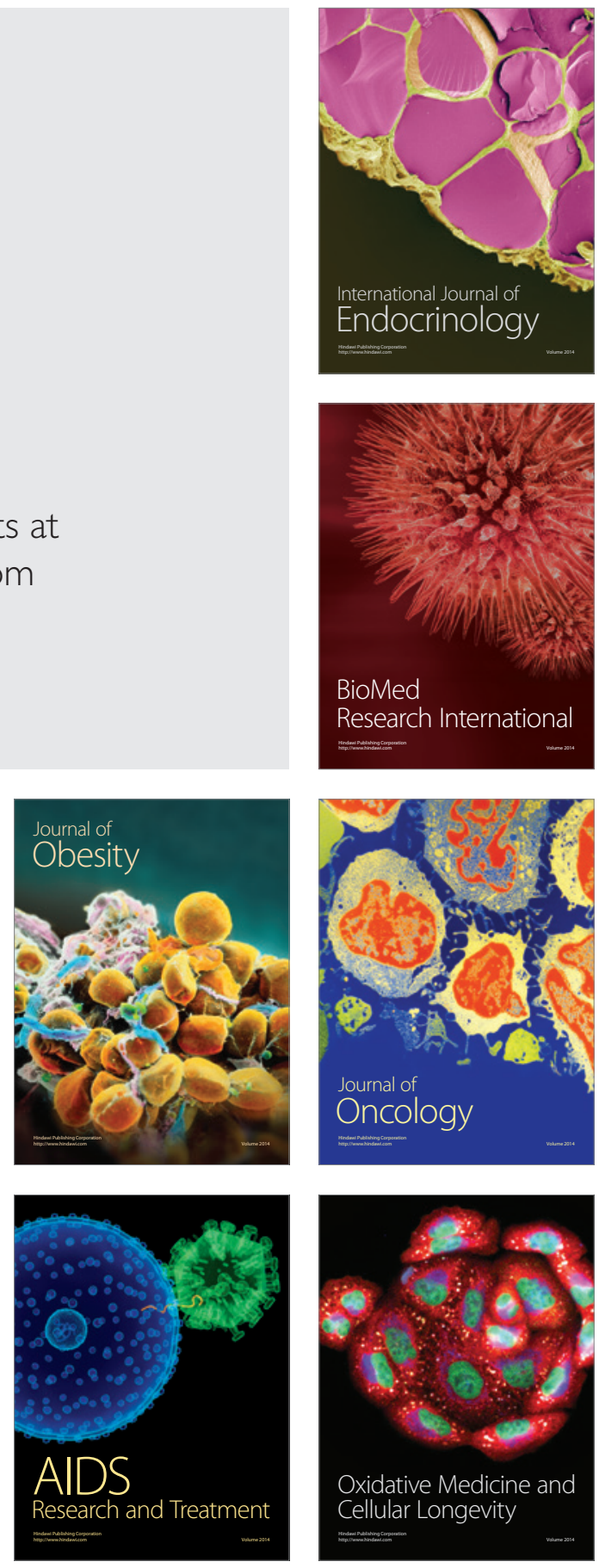